Check for updates

Cite this: RSC Adv., 2019, 9, 35312

Received 7th October 2019

Accepted 24th October 2019

DOI: 10.1039/c9ra08119d

rsc.li/rsc-advances

\section{Marine unsaturated fatty acids: structures, bioactivities, biosynthesis and benefits}

\author{
Yingfang Lu, ${ }^{a}$ Yinning Chen, ${ }^{\mathrm{b}}$ Yulin Wu, ${ }^{\mathrm{a}}$ Huili Hao, ${ }^{\mathrm{a}}$ Wenjing Liang, ${ }^{\mathrm{c}}$ Jun Liu*d \\ and Riming Huang (iD *a
}

Unsaturated fatty acids (UFAs) are an important category of monounsaturated and polyunsaturated fatty acids with nutritional properties. These secondary metabolites have been obtained from multitudinous natural resources, including marine organisms. Because of the increasing numerous biological importance of these marine derived molecules, this review covers 147 marine originated UFAs reported from 1978 to 2018. The review will focus on the structural characterizations, biological properties, proposed biosynthetic processes, and healthy benefits mediated by gut microbiota of these marine naturally originated UFAs.

\section{Introduction}

Fatty acids other than saturated fatty acids (fatty acids that do not contain double bonds are called saturated fatty acids, and all animal oils, except fish oils, contain saturated fatty acids) are unsaturated fatty acids. Unsaturated fatty acids are a kind of fatty acid that makes up body fat. Unsaturated fatty acids (UFAs) consist of a long-chain hydrocarbon with the presence of at least one double covalent bond and ending in a carboxyl group $(-\mathrm{COOH})$, and are distinguished into monounsaturated fatty acids and polyunsaturated fatty acids, both of which have numerous beneficial properties to human health. ${ }^{\mathbf{1 , 2}}$ These secondary metabolites have previously been obtained from a variety of natural resources, including marine fish oils that are a good natural source of these UFAs. ${ }^{3,4}$ In previous decades, marine derived UFAs have attracted a great deal of interest because of their structural diversity and potential biological and nutritional functions. ${ }^{5}$ In particular, research interest in omega3 fatty acids, ${ }^{6}$ eicosapentaenoic acid (EPA) and docosahexaenoic acid (DHA) from marine organisms, has dramatically increased as they are excellent sources of nutrients. These UFAs also can be described as cis fatty acids versus trans fatty acids, which is a description of the geometry of their double bonds. These characteristics in UFAs not only enable them to show a broad

\footnotetext{
${ }^{a}$ Guangdong Provincial Key Laboratory of Food Quality and Safety, College of Food Science, South China Agricultural University, Guangzhou 510642, China. E-mail: luyingfang@stu.scau.edu.cn; DanielWu@stu.scau.edu.cn; hhlhaohuili@stu.scau.edu. cn; huangriming@scau.edu.cn; Tel: +862085283448

${ }^{b}$ Guangdong Polytechnic College, 526100, Zhaoqing, China. E-mail: Yinning_Chen@ $163 . \mathrm{com}$

'Longgang No. 2 Vocational School, Shenzhen, 518104, China.E-mail: 345589207@ qq.com

${ }^{d}$ Laboratory of Pathogenic Biology, Guangdong Medical University, Zhanjiang 524023, China.E-mail: lj2388240@gdmu.edu.cn; Tel: +867592388240
}

range of biological activities, but also allow the development of the nutrient-like physicochemical properties. However, most of marine derived UFAs belong to a relatively unexplored category that may hold a great promise for the potential nutritional application in the future. The structures and potential nutritional applications of UFAs, particularly these with the interesting biological activities have previously been reviewed, ${ }^{7,8}$ but there is still lack of a comprehensive review about marine derived UFAs. Thus, this review aims to summarize 147 marine organisms-derived UFAs published from 1978 to 2018. The review will focus on the structural characterizations, biological properties, proposed biosynthetic processes, and benefits mediated by gut microbiota of these marine UFAs. In addition, the origin of the isolation of these UFAs is also taxonomically presented.

\section{Monounsaturated fatty acids}

Up to date, there are 14 of total monounsaturated fatty acids obtained from marine organisms, linear and branched monounsaturated fatty acids 1-14 (Table 1 and Fig. 1).

\subsection{Linear monounsaturated fatty acids}

2.1.1 Sponges. Only one linear monounsaturated fatty acid, namely, 10-tricosenoic acid $\mathbf{1}$ was isolated from Calyx podatypa. ${ }^{9}$

\subsection{Branched monounsaturated fatty acids}

2.2.1 Sea cubumber. The Caribbean sea cucumber $\mathrm{Hol}$ othuria mexicana contained (6Z)-7-methyloctadec-6-enoic acid 2 that was found in the phospholipid fraction. ${ }^{\mathbf{1 0}}$

2.2.2 Sponges. Two long 2-methyl substituted fatty acids 3 and 4 were isolated as methyl esters from Halichondria panicea (Sea of Japan, Russia). ${ }^{11}$ 7-Methyl-9-oxo-dec-7-enoic acid 5 was isolated from an Ircinia sp. (Red Sea). ${ }^{12}$ 
Table 1 Monounsaturated fatty acids from marine organisms

\begin{tabular}{|c|c|c|c|c|}
\hline Number & Names & Bioactivities & Sources & Reference(s) \\
\hline 2 & (6Z)-7-Methyloctadec-6-enoic acid A & - & Holothuria mexicana & 10 \\
\hline 4 & Not given & - & H. panicea & 11 \\
\hline 5 & Not given & - & Ircinia sp. & 12 \\
\hline 6 & Not given & Antiinflammatory properties & Gracilaria verrucosa & 13 \\
\hline 9 & Not given & - & U. fasciata & 14 \\
\hline 10 & $(2 E, 4 S, 6 S, 8 S)-2,4,6,8$-Tetramethyl-2-undecenoic acid & - & Siphonaria capensis & 15 \\
\hline 11 & Not given & - & S. denticulata & 16 \\
\hline 12 & Not given & - & S. denticulata & 16 \\
\hline 13 & Seco-patulolide & - & unidentified fungal strain & 17 \\
\hline 14 & Not given & - & Sinularia sp. & 18 \\
\hline
\end{tabular}

2.2.3 Algae. An extract with antiinflammatory properties from Gracilaria verrucosa (Jeju Is., S. Korea) yielded a keto fatty acid 6. ${ }^{13}$ A bioactivity-directed analysis of Ulva fasciata (AabuQir, Mediterranean coast, Egypt) characterized three unsaturated fatty acids $\mathbf{7 - 9 .}{ }^{14}$

2.2.4 Limpets. $(2 E, 4 S, 6 S, 8 S)-2,4,6,8$-Tetramethyl-2undecenoic acid $\mathbf{1 0}$ was obtained from the South African pulmonate mollusc Siphonaria capensis. ${ }^{15}$ Two fatty acids 11 and 12 were isolated from the siphonarid limpet Siphonaria denticulata. The structures were confirmed by synthesis. ${ }^{\mathbf{1 6}}$

2.2.5 Microorganisms. An unidentified fungal strain (I96S215), which was obtained from a tissue sample of an unidentified marine sponge collected in Indonesia, produced seco-patulolide 13. ${ }^{17}$

2.2.6 Corals. The absolute configuration of a unsaturated fatty acid 14, isolated from Sinularia sp. (Ishigaki Is., Okinawa), was determined by the Ohrui-Akasaka method. ${ }^{18}$

\section{Polyunsaturated fatty acids}

\subsection{Linear chain polyunsaturated fatty acids}

Up to date, there are 24 of total linear chain polyunsaturated fatty acids 15-38 obtained from marine organisms (Table 2 and Fig. 2).<smiles>CCCCCCCCCCCCCCCCCCCCCCCCCC(=O)O</smiles>

$4 n=6$<smiles>CC(C)(C)C/C=C/C(=O)CC1CCCC1(C)C(=O)O</smiles><smiles>C=CC(O)CCCCC(=O)O</smiles><smiles>CC(C)CC(C)CC=CCCC(C)(C)C(C)(C)CC(C)C(=O)O</smiles>

$11 \mathrm{n}=7, \mathrm{~m}=3$ $12 n=6, m=4$<smiles>CCCC/C=C(\C)CCCCCCCCCCCC</smiles>

2<smiles>CC(=O)C=C(C)CCCCCC(=O)O</smiles>

5<smiles>[R][R]([R])[R](=O)C=CCCCCC</smiles><smiles>CCCC(I)CC(I)CC(I)/C=C(\C)C(=O)O</smiles><smiles>CC(O)CCCCCCC(O)C=CC(=O)O</smiles>

\section{4}

Fig. 1 Structures of monounsaturated fatty acids from marine organisms. 
Table 2 Linear polyunsaturated fatty acids from marine organisms

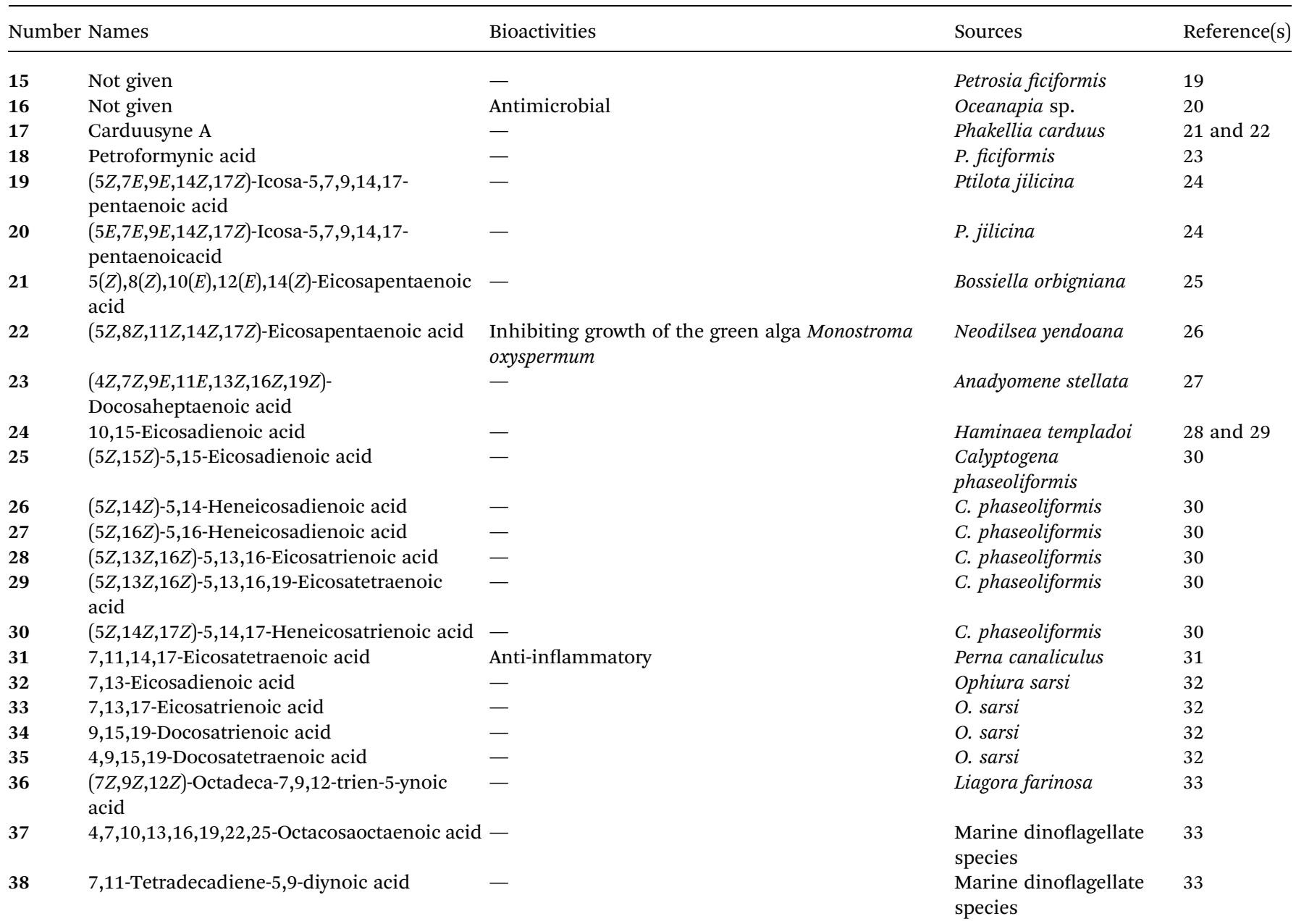

3.1.1 Sponges. One polyacetylene 15 was isolated from Petrosia ficiformis, but, as in several earlier examples, the structure was only partially elucidated. ${ }^{19}$ The antimicrobial constituent of a Japanese Oceanapia sp. was identified as the bis-acetylene $16 .^{20}$ One acetylenic acid, carduusyne A 17, identified as the corresponding ethyl ester, was obtained from a specimen of Phakellia carduus obtained from a depth of $350 \mathrm{~m}$ by trawling. ${ }^{21}$ The compound $\mathbf{1 7}$ has been confirmed by a stereocontrolled synthesis. ${ }^{22}$ One additional polyacetylene, petroformynic acid 18, was isolated from both Atlantic and Mediterranean specimens of Petrosia ficiformis. ${ }^{23}$

3.1.2 Algae. The temperate red alga Ptilota jilicina contained $(5 Z, 7 E, 9 E, 14 Z, 17 Z)$-icosa-5,7,9,14,17-pentaenoic acid 19 and $(5 E, 7 E, 9 E, 14 Z, 17 Z)$-icosa-5,7,9,14,17-pentaenoicacid 20, both of which were isolated as the corresponding methyl esters. ${ }^{24}$ Aqueous extracts of Bossiella orbigniana catalyse the enzymatic oxidation of arachidonic acid to bosseopentaenoic acid, $5(Z), 8(Z), 10(E), 12(E), 14(Z)$-eicosapentaenoic acid 21, which was isolated from extracts of the alga. ${ }^{25}$ An allelopathic substance from Neodilsea yendoana that inhibited growth of the green alga Monostroma oxyspermum was identified as $(5 Z, 8 Z, 11 Z, 14 Z, 17 Z)$-eicosapentaenoic acid $\mathbf{2 2 .}^{{ }^{26}}$ A polyunsaturated fatty acid, $(4 Z, 7 Z, 9 E, 11 E, 13 Z, 16 Z, 19 Z)$-docosaheptaenoic acid 23, was encountered in Anadyomene stellata from Florida. ${ }^{27}$

3.1.3 Mollusc. The eicosanoid 24, which was isolated from Haminaea templadoi ${ }^{28}$ was synthesized in five steps. ${ }^{29}$ A series of n-4 polyunsaturated fatty acids including 25-30 were reported from the deep-sea clam Calyptogena phaseoliformis (Japan Trench). ${ }^{30}$ A homologous series of $\omega-3$ polyunsaturated fatty acids, with 7,11,14,17-eicosatetraenoic acid 31 dominating, were isolated as anti-inflammatory components of the greenlipped mussel Perna canaliculus (New Zealand). ${ }^{31}$

3.1.4 Echinoderm. Four nonmethylene interrupted polyunsaturated fatty acid derivatives 32-35 were identified in extracts of the brittle star Ophiura sarsi. ${ }^{32}$

3.1.5 Others. Among the lipids of Liagora farinosa were four compounds that can be differentiated by UV absorption and/or the presence of an acetylene functionality. The metabolite, (7Z,9Z,12Z)-octadeca-7,9,12-trien-5-ynoic acid 36, was ichthyotoxic. ${ }^{33}$ Two very long, highly unsaturated fatty acids 37 and 38 were isolated from seven marine dinoflagellate species. $^{34}$ 


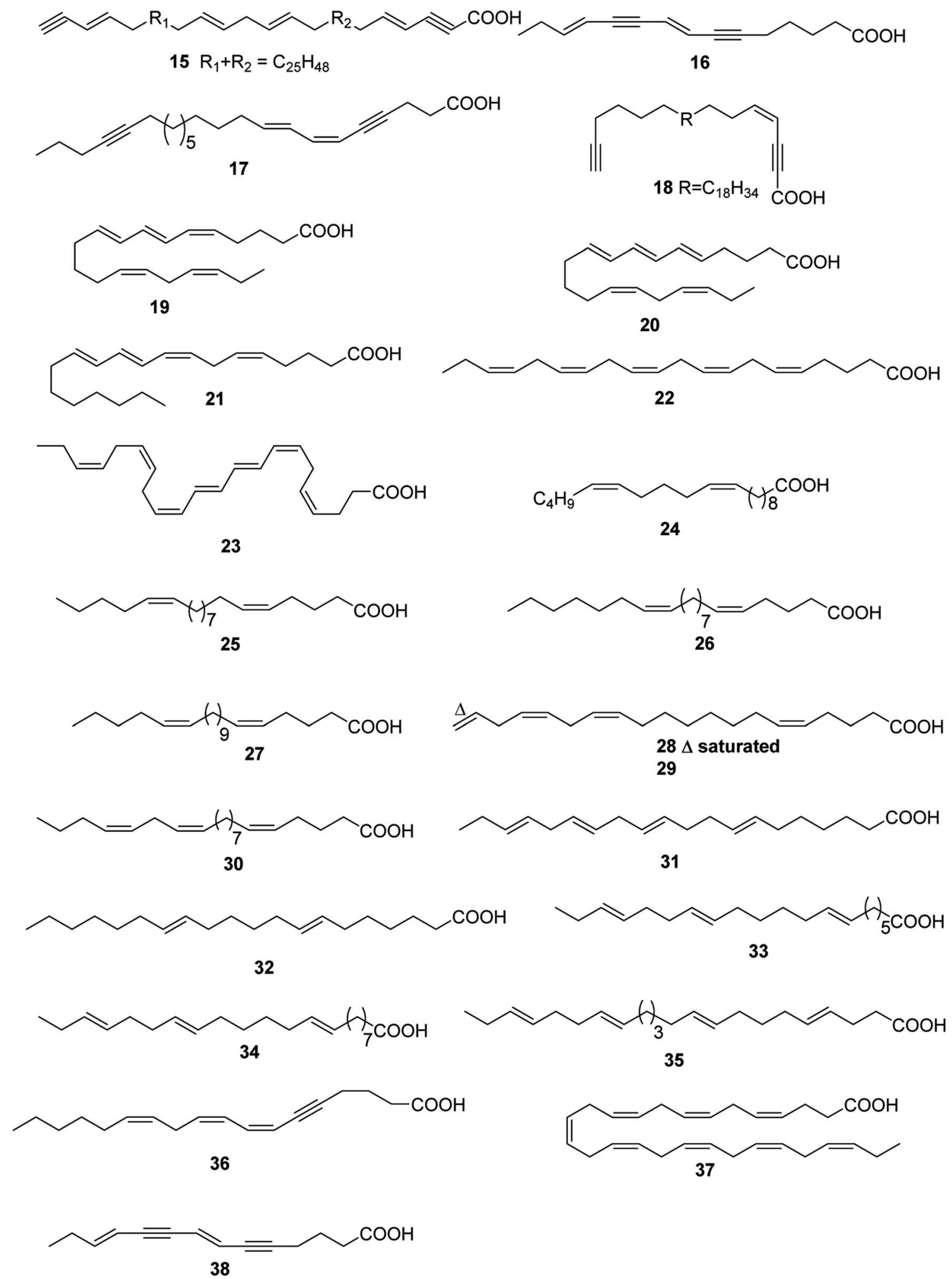

Fig. 2 Structures of linear chain polyunsaturated fatty acids from marine organisms.

\subsection{Branched chain polyunsaturated fatty acids}

Up to date, there are 109 of total linear chain polyunsaturated fatty acids 39-147 obtained from marine organisms (Tables 3-5 and Fig. 3-5).
3.2.1 Sponges. Acetylenic acids, 39-42, identified as the corresponding ethyl esters, were obtained from a specimen of Phakellia carduus obtained from a depth of $350 \mathrm{~m}$ by trawling. ${ }^{21}$ Studies on the biosynthesis of the branched fatty acids $\mathbf{4 3}$ and 
Table 3 Branched chain polyunsaturated fatty acids from sponges

\begin{tabular}{|c|c|c|c|c|}
\hline Number & Names & Bioactivities & Sources & Reference(s) \\
\hline 39 & Not given & - & P. carduus & 21 \\
\hline 40 & Not given & - & P. carduus & 21 \\
\hline 42 & Not given & - & P. carduus & 21 \\
\hline 43 & $\begin{array}{l}(Z, Z)-25 \text {-Methyl-5,9- } \\
\text { hexacosadienoic acid }\end{array}$ & - & Jaspis stellifera & 35 \\
\hline 45 & $\begin{array}{l}(5 Z, 9 Z) \text {-Hexadeca-5,9- } \\
\text { dienoic acid }\end{array}$ & - & Chondrilla nucula & 36 \\
\hline 46 & $\begin{array}{l}5,8,10,14,17- \\
\text { Eicosapentaenoic acid }\end{array}$ & - & Echinochalina mollis & 37 \\
\hline 47 & Not given & - & E. mollis & 37 \\
\hline 48 & $\begin{array}{l}4,7,10,12,16,19- \\
\text { Docosahexaenoic acid }\end{array}$ & - & E. mollis & 37 \\
\hline 52 & Petrosolic acid & $\begin{array}{l}\text { Inhibited HIV reverse } \\
\text { transcriptase }\end{array}$ & Petrosia sp. & 40 \\
\hline 53 & Corticatic acid A & Antifungal & Petrosia corticata & 41 \\
\hline 54 & Corticatic acid B & Antifungal & P. corticata & 41 \\
\hline 55 & Corticatic acid C & Antifungal & P. corticata & 41 \\
\hline 56 & Nepheliosyne A & - & Xestospon & 42 \\
\hline 57 & Triangulynic acid & $\begin{array}{l}\text { Against leukemia and colon } \\
\text { tumour lines }\end{array}$ & Pellina triangulata & 43 \\
\hline 58 & Pellynic acid & $\begin{array}{l}\text { Inhibited inosine } \\
\text { monophosphate } \\
\text { dehydrogenase in vitro }\end{array}$ & P. triangulata & 44 \\
\hline 59 & Aztequynol A & - & Petrosia sp. & 45 \\
\hline 68 & Haliclonyne & - & Haliclona sp. & 47 \\
\hline 69 & Callyspongynic acid & $\alpha$-glucosidase inhibitor & P. corticata & 41,48 and 49 \\
\hline 70 & Corticatic acid D & $\begin{array}{l}\text { Geranylgeranyltransferase } \\
\text { type I inhibitor }\end{array}$ & P. corticata & 41,48 and 49 \\
\hline 71 & Corticatic acid E & & P. corticata & 41,48 and 49 \\
\hline 72 & $\begin{array}{l}\text { (5Z,9Z)-22-Methyl-5,9- } \\
\text { tetracosadienoic acid }\end{array}$ & $\begin{array}{l}\text { Cytotoxic activity against } \\
\text { mouse Ehrlich carcinoma } \\
\text { cells and a hemolytic effect } \\
\text { on mouse erythrocytes }\end{array}$ & Stelletta sp. & 50 \\
\hline 73 & Stellettic acid C & $\begin{array}{l}\text { Exhibited marginal to } \\
\text { moderate toxicity to five } \\
\text { human tumour cell lines }\end{array}$ & Stelletta sp. & 51 \\
\hline 74 & Not given & $\begin{array}{l}\text { Cytotoxic to human } \\
\text { leukemia cells }\end{array}$ & Stelletta sp. & 52 \\
\hline 75 & Petroformynic acid B & Cytotoxic & Petrosia & 53 \\
\hline 76 & Petroformynic acid C & & Petrosia & 53 \\
\hline 77 & Heterofibrin $A_{1}$ & $\begin{array}{l}\text { Inhibited lipid droplet } \\
\text { formation }\end{array}$ & Spongia sp. & 54 \\
\hline 78 & Officinoic acid B & - & Spongia officinalis & 55 \\
\hline 79 & Fulvyne A & $\begin{array}{l}\text { Against a chloramphenicol- } \\
\text { resistant strain of Bacillus } \\
\text { subtilis }\end{array}$ & Haliclona fulva & 56 \\
\hline 80 & Fulvyne B & & H. fulva & 56 \\
\hline 81 & Fulvyne C & & H. fulva & 56 \\
\hline 82 & Fulvyne D & & H. fulva & 56 \\
\hline
\end{tabular}


Table 3 (Contd.)

\begin{tabular}{llll}
\hline Number & Names & Bioactivities & Sources \\
\hline $\mathbf{8 3}$ & Fulvyne E & & H. fulva \\
$\mathbf{8 4}$ & Fulvyne F & & H. fulva \\
$\mathbf{8 5}$ & Fulvyne G & & H. fulva \\
$\mathbf{8 6}$ & Fulvyne H & & H. fulva \\
$\mathbf{8 7}$ & Fulvyne I & - & H. fulva \\
$\mathbf{8 8}$ & Petrosynic acid A & - & Petrosia sp. \\
$\mathbf{8 9}$ & Petrosynic acid B & - & Petrosia sp. \\
$\mathbf{9 0}$ & Petrosynic acid C & - & Petrosia sp. \\
$\mathbf{9 1}$ & Petrosynic acid D & & Petrosia sp.
\end{tabular}

44 (from Jaspis stellifera) indicated that the unusual long-chain fatty acids were formed by elongation of shorter branched fatty acids, and that methyl branching did not occur after elongation of the chain. ${ }^{35}$ An unusually short fatty acid, $(5 Z, 9 Z)$-hexadeca5,9-dienoic acid 45, was obtained from Chondrilla nucula. ${ }^{36}$ Relatively large amounts of the eicosanoids 46 and 47 and hydroxy acids 48 and 49 were found in Echinochalina mollis from the Coral Sea; they were isolated as the corresponding methyl esters and identified by interpretation of spectral data. ${ }^{37} \mathrm{~A}$ stereoselective route to the methyl branched $(5 Z, 9 Z)$-eicosa-5,9dienoic acids $\mathbf{5 0}$ and $\mathbf{5 1}$ found in Erylus forrnosus ${ }^{38}$ has been described. ${ }^{39}$ Petrosolic acid 52 that inhibited HIV reverse transcriptase was the constituent of a Red Sea Petrosia sp..$^{40}$ Corticatic acids A-C 53-55 are antifungal acetylenicacids from Petrosia corticata from Japanese waters. ${ }^{41}$ Spectroscopic analysis had resulted in a tentative structure for nepheliosyne A $\mathbf{5 6}$ from an Okinawan sponge of the genus Xestospon. ${ }^{42}$ Pellina triangulata from Truk in Micronesia contained triangulynic acid 57, which is a cytotoxic polyacetylene that was most active against leukemia and colon tumour lines. ${ }^{43}$ Pellynic acid 58, which inhibited inosine monophosphate dehydrogenase in vitro, was obtained from Pellina triangulata from Chuuk (Truk) Atoll. ${ }^{44}$ Aztequynols A 59 and B 60 were C-branched acetylenes from a Petrosia sp. from New Caledonia. ${ }^{45}$ A more complex series of highly oxygenated $\mathrm{C} 47$ polyacetylenes, osirisynes A-F 61-66, were isolated as cytotoxins from a Korean specimen of Haliclona osiris. ${ }^{46}$ One polyacetylene, aikupikanynes F 67 was obtained from a Callyspongia sp. from the Red Sea. ${ }^{20}$ The polyacetylene carboxylic acid haliclonyne $\mathbf{6 8}$ was obtained from a Haliclona sp. from the Red Sea. ${ }^{47}$ Japanese specimens of Callyspongia truncata yielded the $\alpha$-glucosidase inhibitor callyspongynic acid $\mathbf{6 9}^{48}$ while corticatic acids D $\mathbf{7 0}$ and E $\mathbf{7 1}^{\mathbf{4 1}}$ were isolated from a Japanese Petrosia corticata and were found to be geranylgeranyltransferase type I inhibitors. ${ }^{49}$

A cytotoxic fatty acid, (5Z,9Z)-22-methyl-5,9tetracosadienoic acid 72 was isolated from Geodinella robusta collected from the Sea of Okhotsk, Russia. ${ }^{50}$ An undescribed Korean species of Stelletta was found to contain a cytotoxic acetylenic acid: stellettic acid C $\mathbf{7 3}$ that exhibited marginal to moderate toxicity to five human tumour cell lines. ${ }^{51}$ From a seemingly identical Stelletta species, collected at a different Korean location, a desmethoxy analogue 74, was isolated; it was mildly cytotoxic to human leukemia cells. ${ }^{52}$ The cytotoxic petroformynic acids B 75 and C 76 were obtained from a Petrosia species (Katsuo-jim Is., Wakayama Pref., Japan). ${ }^{53}$ One acetylenic compound heterofibrin $\mathrm{A}_{1} 77$ was isolated from a Spongia (Heterofibria) sp. collected by dredging in the Great Australian Bight. Heterofibrin $\mathrm{A}_{1}$ inhibited lipid droplet formation at $10 \mathrm{mM}$ yet was not cytotoxic at similar concentrations. ${ }^{54}$ Officinoic acid B 78 is linear diterpene from Spongia officinalis (off Mazara del Vallo, Sicily). ${ }^{55}$ An extract of Haliclona fulva (Procida Is., Gulf of Naples, Italy) contained the nine acetylenes fulvyne A-I 7987. ${ }^{56}$ Petrosynic acids A-D 88-91 (Petrosia sp., Tutuila, American Samoa) all displayed similar activity versus various HTCLs and non-proliferative human fibroblasts and hence no therapeutic window is available. ${ }^{57}$

3.2.2 Algae. Malyngic acid 92 is not the acid that is associated with the malyngamides, but it has been shown to be $(10 E, 15 Z)-(9 S, 12 R, 13 S)-9,12,13$-trihydroxyoctadeca-10,14-dienoicacid..$^{58}$ Unlike most metabolites from Lyngbya majuscula, malyngic acid was found in both shallow- and deep-water varieties. Research on Laurencia hybrida indicated that these lipid pools might contain undescribed bioactive metabolites. The antimicrobial constituents $(5 Z, 8 E, 10 E)$-11-fomylundeca-5,8,10trienoic acid 93 and $(2 Z, 5 Z, 7 E, 11 Z, 14 Z)-9$-hydroxyeicosa2,5,7,11,14-pentaenoic acid $\mathbf{9 4}$ might be considered as primary metabolites were it not for their bioactivity. ${ }^{59}$ The additional acyclicditerpene $\mathbf{9 5}$ has been reported from Bifurcaria bifurcate. ${ }^{60}$ Ptilodene 96 is an eicosanoid from Ptilota filicina that inhibited both 5-lipoxygenase and $\mathrm{Na}^{+} / \mathrm{K}^{+}$ATPase. ${ }^{61} 12-(S)$ Hydroxyeicosapentaenoic acid $\mathbf{9 7}$, which is a potent inhibitor of platelet aggregation, has been isolated in large quantities from Murrayella periclados and has been recognized as the compound previously identified ${ }^{62}$ as 9-hydroxypentaenoic acid 98 from Laurencia hybrid. ${ }^{63}$ The structure of turbinaric acid 99, which is a cytotoxic constituent of Turbinaria ornata, was elucidated from spectral data and confirmed by synthesis. ${ }^{64}$ A notable exception was the report of three biologically active eicosanoids, $(12 R, 13 R)$-dihydroxyeicosa-5(Z),8(Z),10(E),14(Z)-tetraeonic acid 100, $(12 R, 13 R)$-dihydroxyeicosa-5 $(Z), 8(E), 10(E), 14(Z), 17(Z)$-pentaenoic acid 101, and $(10 R, 11 R)$-dihydroxyoctadeca$6(Z), 8(E), 12(Z)$-trienoic acid 102 that were isolated from the temperate red alga Farlowia mollis. ${ }^{65}$ The structure of 
Table 4 Branched chain polyunsaturated fatty acids from algae

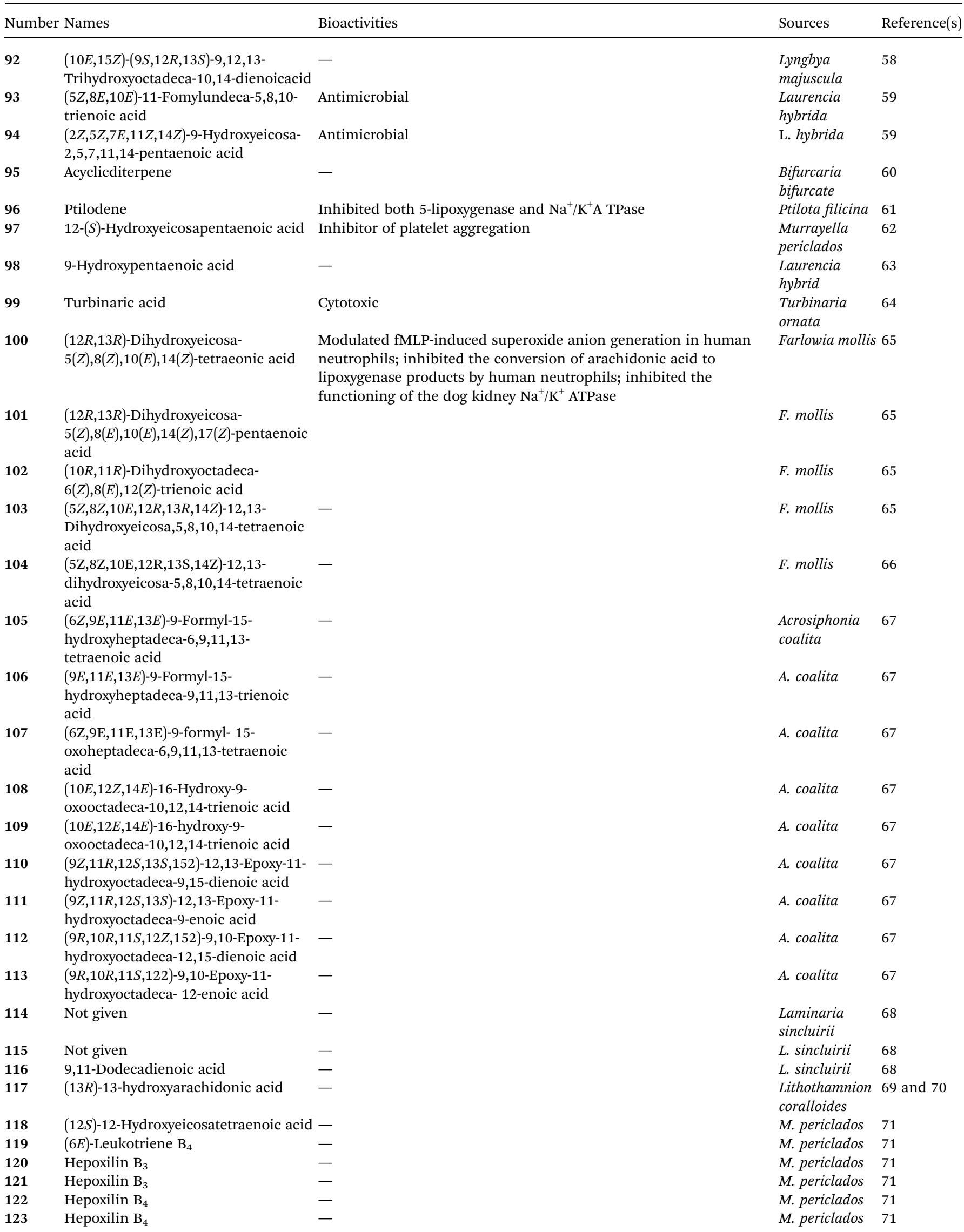


Table 4 (Contd.)

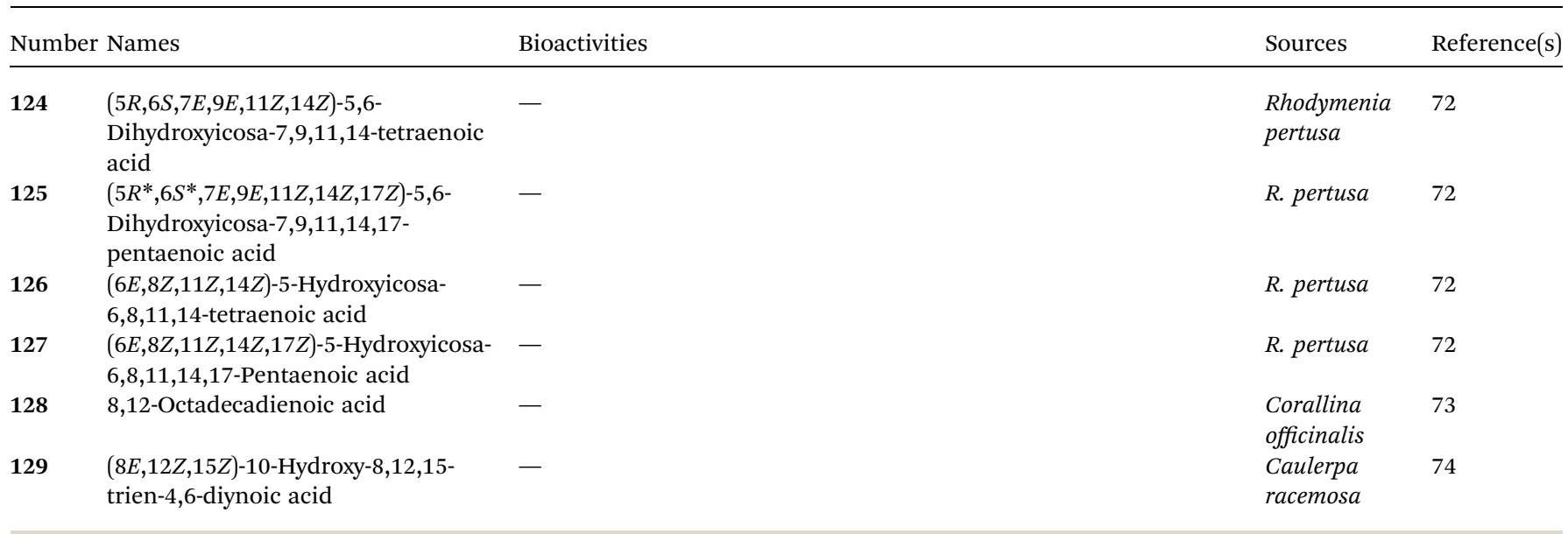

a dihydroxy eicosanoid isolated from the red alga Farlowia mollis has been revised from $(5 Z, 8 Z, 10 E, 12 R, 13 R, 14 Z)-12,13-$ dihydroxyeicosa,5,8,10,14-tetraenoic acid $\mathbf{1 0 3}^{\mathbf{6 5}}$ to $(5 Z, 8 Z, 10 E, 12 R, 13 S, 14 Z)-12,13$-dihydroxyeicosa-5,8,10,14tetraenoic acid $\mathbf{1 0 4}$ as a result of the synthesis of the both threo and erythro isomers. ${ }^{66}$
The green alga Acrosiphonia coalita contains the oxylipins coalital, which may be an artefact caused by photoisomerization of the natural product, racemic $(6 Z, 9 E, 11 E, 13 E)$-9-formyl-15hydroxyheptadeca-6,9,11,13-tetraenoic acid 105, $(9 E, 11 E, 13 E)$ 9-formyl-15-hydroxyheptadeca-9,11,13-trienoic acid 106, $(6 Z, 9 E, 11 E, 13 E)$-9-formyl-15-oxoheptadeca-6,9,11,13-tetraenoic

Table 5 Branched chain polyunsaturated fatty acids from Coelenterate, Marine fungus, Arthropoda, Bacterium

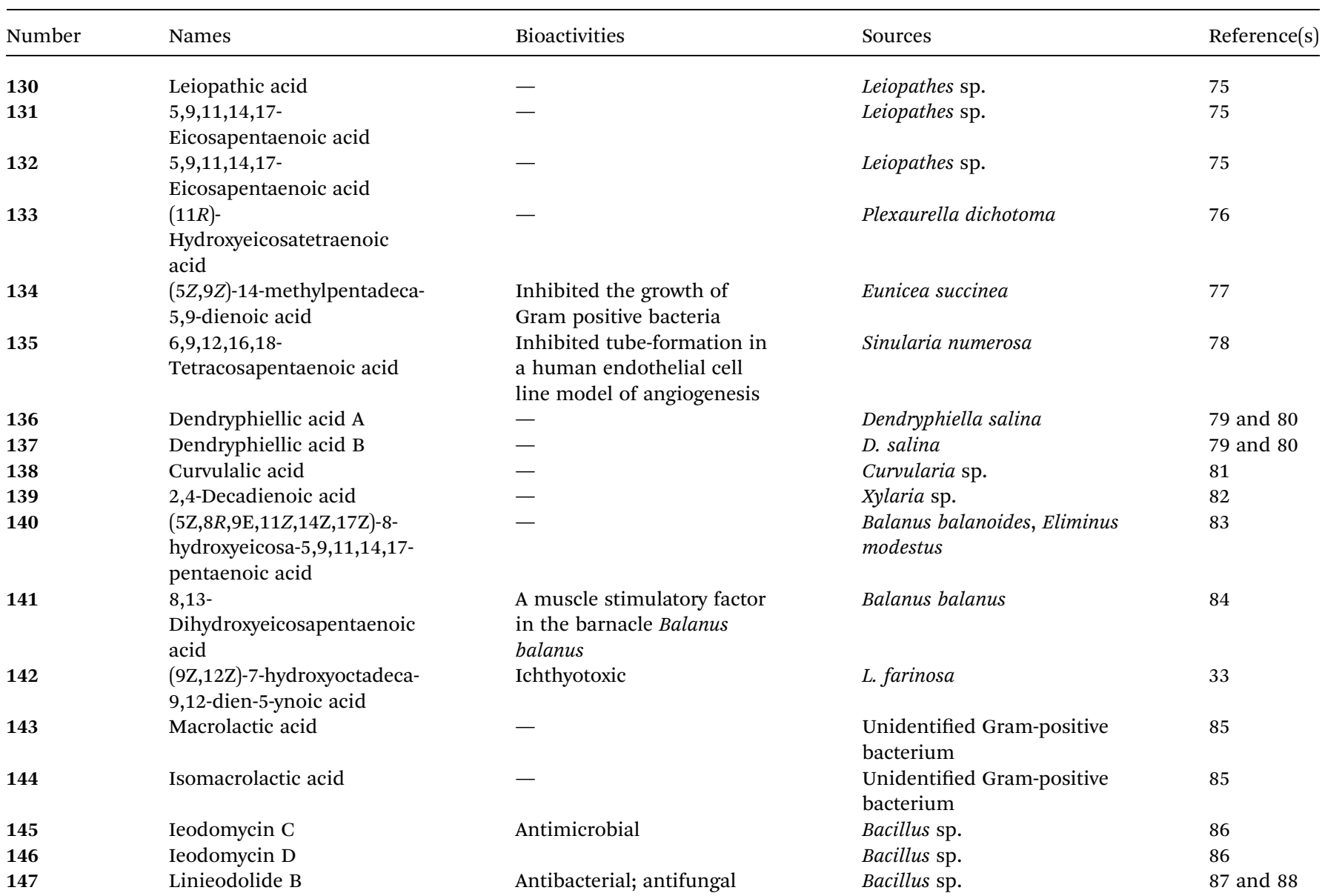



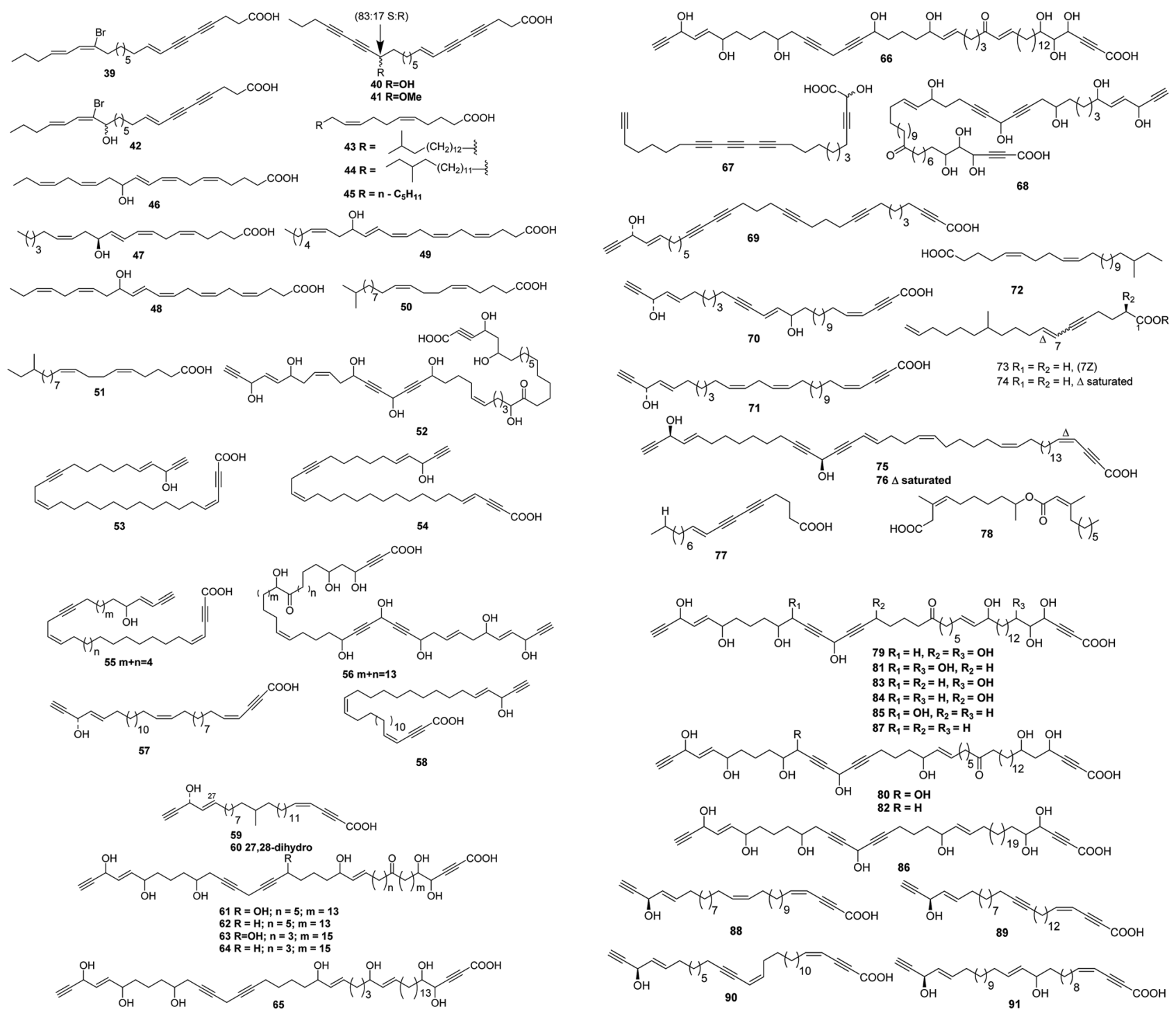

Fig. 3 Structures of branched chain polyunsaturated fatty acids from sponges.

acid 107, (10E,12Z,14E)-16-hydroxy-9-oxooctadeca-10,12,14trienoic acid 108, (10E,12E,14E)-16-hydroxy-9-oxooctadeca10,12,14-trienoic acid 109, (9Z,11R,12S,13S,152)-12,13-epoxy11-hydroxyoctadeca-9,15-dienoic acid 110, $(9 Z, 11 R, 12 S, 13 S)$ 12,13-epoxy-11-hydroxyoctadeca-9-enoic acid $(9 R, 10 R, 11 S, 12 Z, 152)-9,10$-epoxy-11-hydroxyoctadeca-12,15-

dienoic acid 112, and $(9 R, 10 R, 11 S, 122)-9,10-$ epoxy-11hydroxyoctadeca-12-enoic acid 113, the acids all being isolated as the corresponding methyl esters. ${ }^{67}$ Three divinyl ethers, 114116, were isolated along with a number of hydroxylated fatty acids from the Oregon brown alga Laminaria sincluirii and were identified by interpretation of spectral evidence. ${ }^{68}$ The absolute stereochemistry of (13R)-13-hydroxyarachidonic acid 117 , which is a known eicosanoid from Lithothamnion coralloides, ${ }^{69}$ was determined by degradation and its biosynthesis from arachidonic acid was studied. ${ }^{70}$

The Caribbean alga Murrayella periclados contains a number of eicosanoids that include (12S)-12-hydroxyeicosatetraenoic acid 118, (6E)-leukotriene $\mathrm{B}_{4}, 119$ and erythro and threo isomers of hepoxilins $\mathrm{B}_{3}, \mathbf{1 2 0} / \mathbf{1 2 1}$ and $\mathrm{B}_{4}, \mathbf{1 2 2} / \mathbf{1 2 3}{ }^{71}$ Four oxylipins (5R,6S,7E,9E,11Z,14Z)-5,6-dihydroxyicosa-7,9,11,14-tetraenoic acid 124, $\left(5 R^{*}, 6 S^{*}, 7 E, 9 E, 11 Z, 14 Z, 17 Z\right)-5,6$-dihydroxyicosa7,9,11,14,17-pentaenoic acid 125, (6E,8Z,11Z,14Z)-5hydroxyicosa-6,8,11,14-tetraenoic acid 126, and (6E,8Z,11Z,14Z,17Z)-5-hydroxyicosa-6,8,11,14,17-pentaenoic acid 127 were isolated from Rhodymenia pertusa..$^{72}$ An oxylipin 128 was obtained from Aspergillus flavus, (red alga Corallina officinalis, Yantai, China). ${ }^{73}$ Studies on a Caulerpa racemosa (Zhanjiang coastline, China) led to the isolation of the acetylenic fatty acid $(8 E, 12 Z, 15 Z)-10$-hydroxy-8,12,15-trien-4,6diynoic acid $129 .^{74}$

3.2.3 Coelenterate. Leiopathic acid 130 and two known eicosanoids, 131 and 132, were isolated from a black coral, Leiopathes sp., collected at St Paul Island in the South India Ocean. ${ }^{75}$. (11R)-Hydroxyeicosatetraenoic acid 133, a proposed intermediate on the pathway to prostanoids in coelenterates, has 


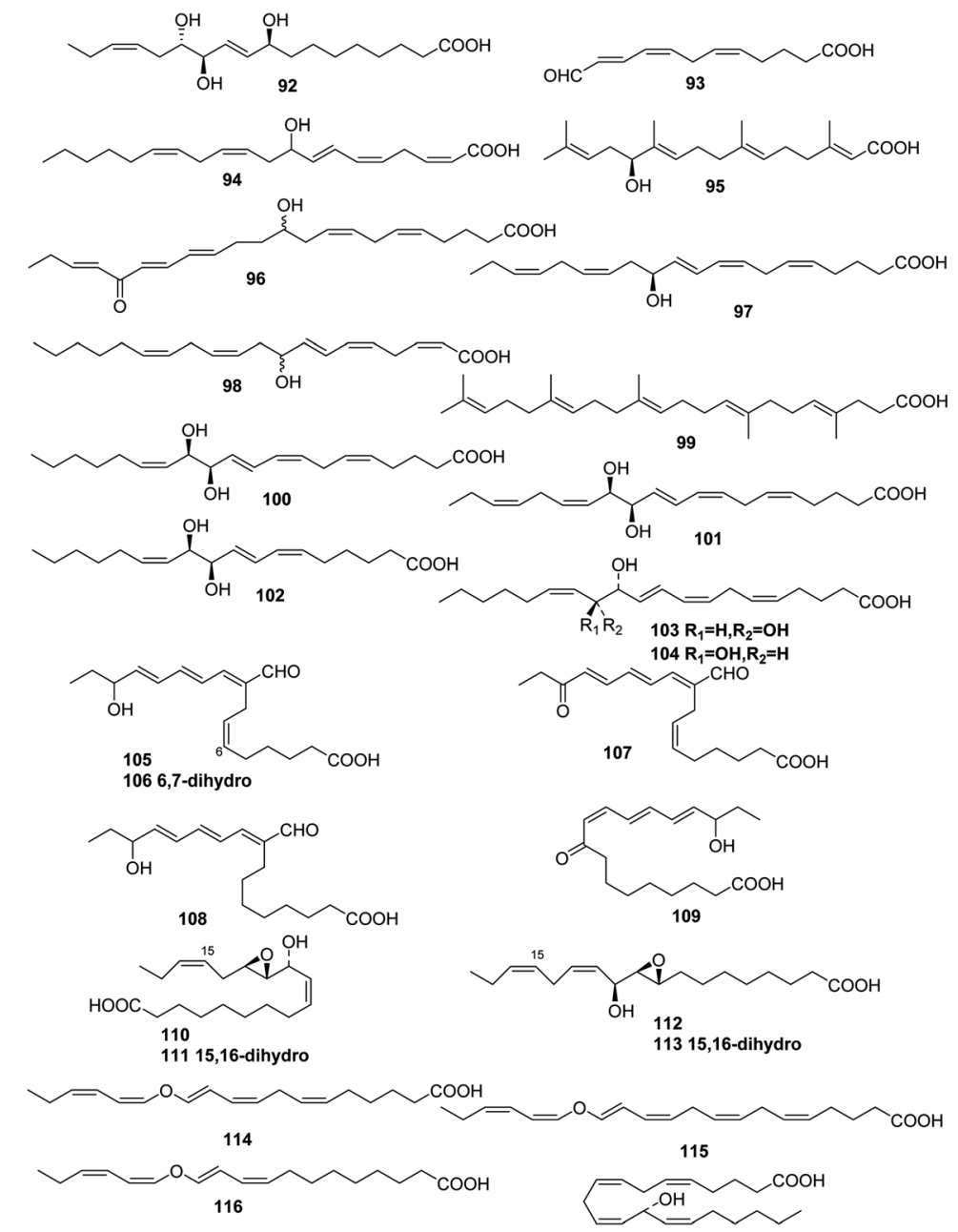

117
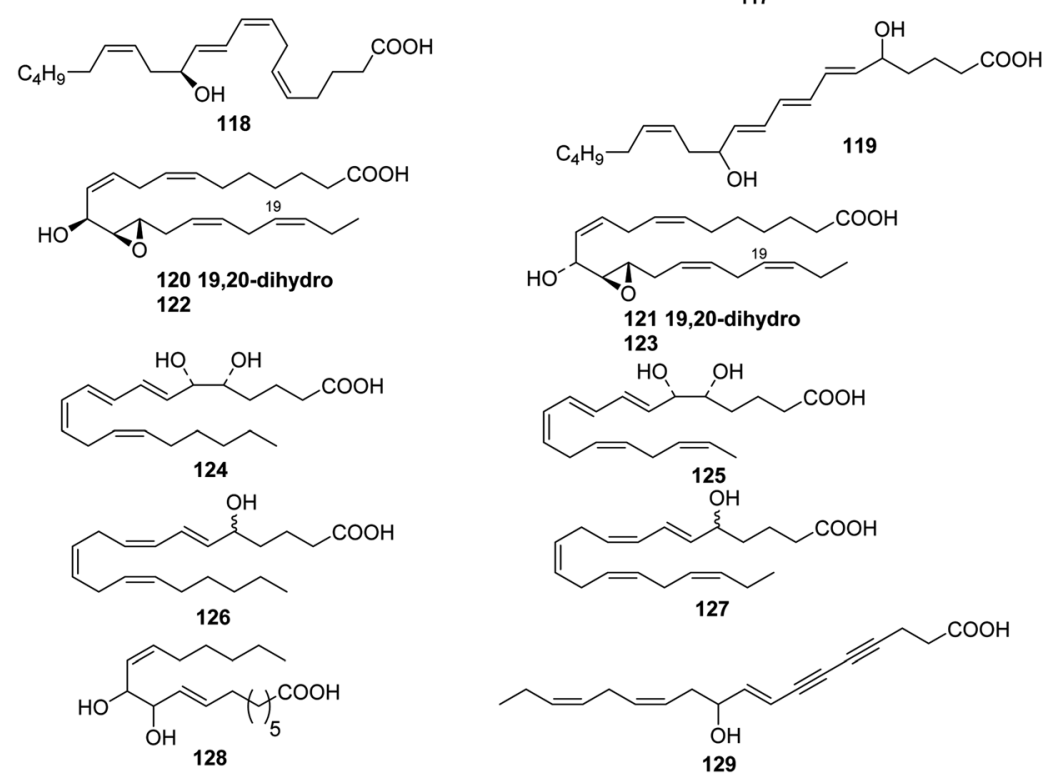

Fig. 4 Structures of branched chain polyunsaturated fatty acids from marine algae.

been found in the gorgonian Plexaurella dichotoma. ${ }^{76}$ The gorgonian Eunicea succinea contained (5Z,9Z)-14-methylpentadeca-5,9-dienoic acid 134, which inhibited the growth of Gram positive bacteria.77
Oxylipin 135, isolated by bioassay-directed fractionation (Sinularia numerosa, Kagoshima Prefecture, Japan), inhibited tube-formation in a human endothelial cell line model of angiogenesis. ${ }^{78}$ 


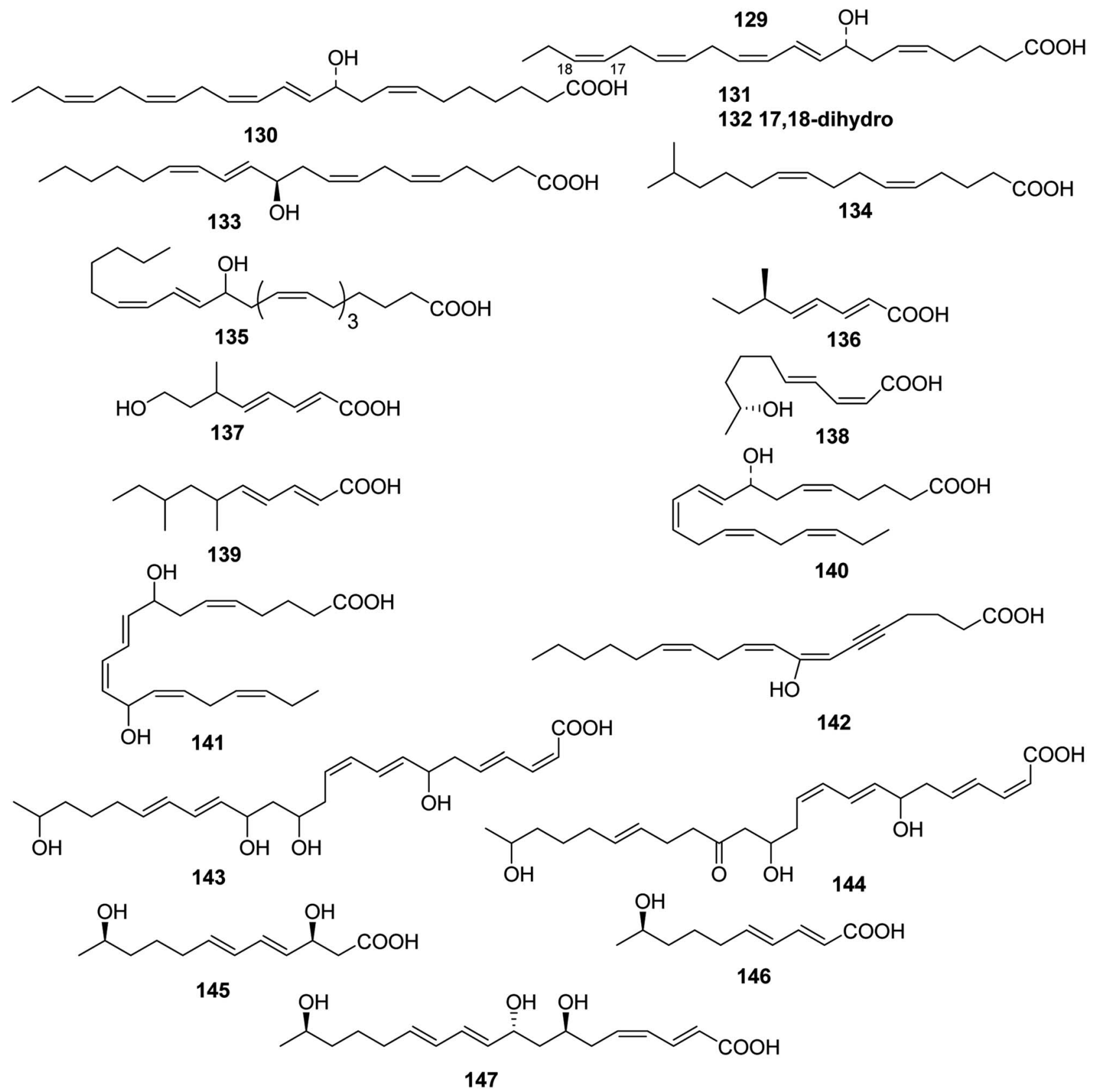

Fig. 5 Structures of branched chain polyunsaturated fatty acids from Coelenterate, Marine fungus, Arthropoda, Bacterium.

3.2.4 Marine fungus. The marine deuteromycete Dendryphiella salina produced an unusual group of trinoreremophilane and eremophilane derivatives. ${ }^{79}$ The structures of dendryphiellic acids A 136 and B 137 were proposed on the basis of spectral and chemical studies as well as comparison of their spectral data with those of dendryphiellin A. ${ }^{80}$ A Curvularia sp. (sea fan Annella species, Similan Islands, Phangnga, Thailand) yielded the metabolites curvulalic acid 138. ${ }^{81}$ The lipid 139 was obtained from Xylaria sp. $^{\mathbf{8 2}}$

3.2.5 Arthropoda. The structure of the hatching factor of the barnacles Balanus balanoides and Eliminus modestus has been confirmed by synthesis to be $(5 Z, 8 R, 9 E, 11 Z, 14 Z, 17 Z)-8$ - hydroxyeicosa-5,9,11,14,17-pentaenoic acid $140 .^{83}$ 8,13-Dihydroxyeicosapentaenoic acid $\mathbf{1 4 1}$ was identified as a muscle stimulatory factor in the barnacle Balanus balanus. ${ }^{\mathbf{8 4}}$

3.2.6 Bacterium. The metabolite, (9Z,12Z)-7hydroxyoctadeca-9,12-dien-5-ynoic acid 142, was ichthyotoxic. ${ }^{33}$ An unidentified Gram-positive bacterium from a deep-sea sediment core produced macrolactic acid 143 and isomacrolactic acid $144 .^{85}$ The fatty acids, ieodomycins C 145 and D 146 from Bacillus sp. (sediment, Ieodo, South Korea) had broad spectrum antimicrobial activity. ${ }^{86}$ Bacillus sp. (sediment, Ieodo Reef, S. Korea) ${ }^{87}$ produced the unsaturated fatty acid linieodolide B 147, with modest antibacterial and antifungal activity. ${ }^{\mathbf{8}}$ 


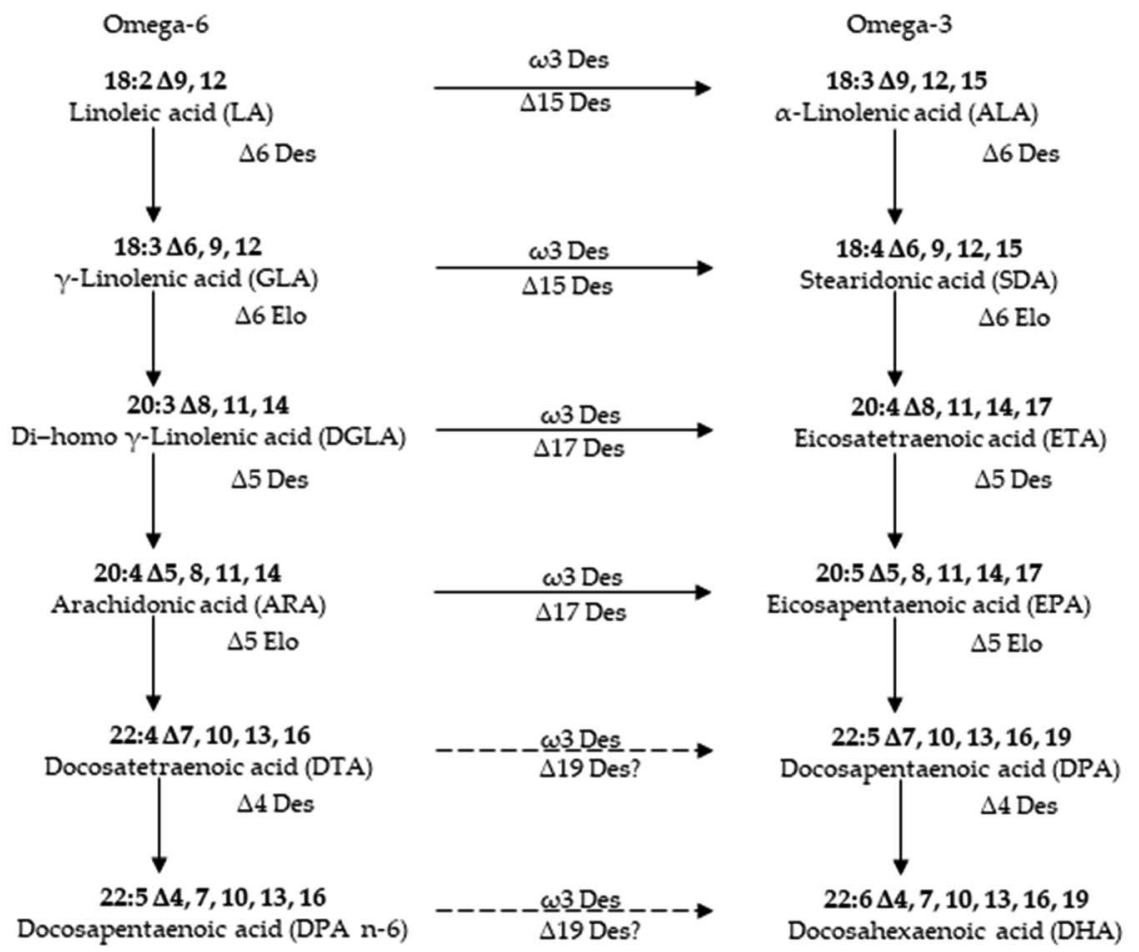

Fig. 6 Pathway for the biosynthesis of long chain polyunsaturated fatty acids in microalgae.

\section{Biosynthetic pathways}

PUFAs are gaining importance due to their innumerable health benefits. The most common source of PUFAs is of marine origin. Hence, understanding their biosynthesis in marine origin has attained prominence in recent years. ${ }^{\mathbf{8 9}, 90}$ Rabbitfish Siganus canaliculatus was the first marine teleost demonstrated to have the ability to biosynthesize C20-22 long-chain polyunsaturated fatty acid (LC-PUFA) from C18 PUFA precursors, which is generally absent or low in marine teleosts. ${ }^{91}$ The marine diatom Phaeodactylum tricornutum accumulates eicosapentaenoic acid (EPA, 20:5n-3) as its major component of fatty acids. To improve the EPA production, delta 5 desaturase, which plays a role in EPA biosynthetic pathway, was characterized in marine diatom Phaeodactylum tricornutum. ${ }^{90}$ There is currently considerable interest in understanding how the biosynthetic pathways of highly unsaturated fatty acids (HUFA) are regulated in fish. The aim is to know if it is possible to replace fish oils (FO), rich in HUFA, by vegetable oils (VO), poor in HUFA and rich in their 18 carbon fatty acid precursors, in the feed of cultured fish species of commercial importance. ${ }^{92}$ Although many better insights into the synthesis of eicosapentaenoic acid (EPA) and docosahexaenoic acid (DHA) in marine microalgae, ${ }^{93}$ there are still a little known about

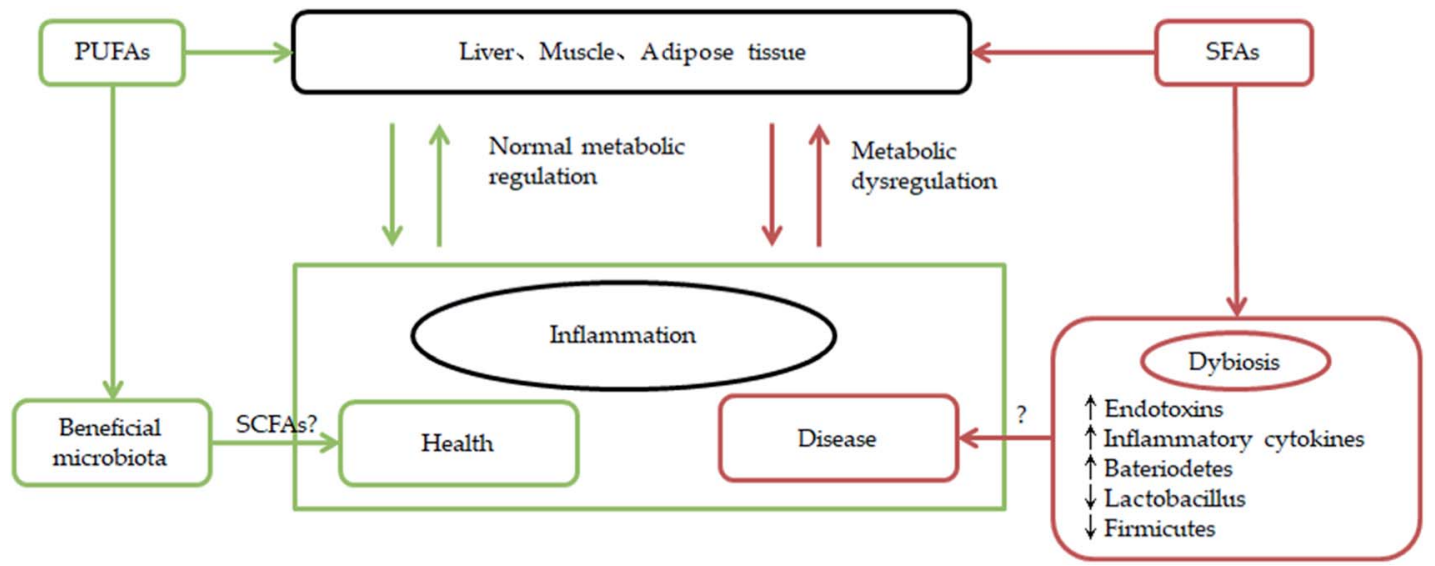

Fig. 7 Impact of SFA and PUFA on gut microbiota and metabolic regulation. 


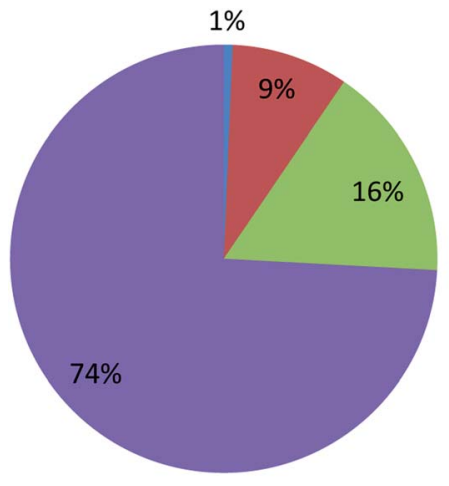

Linear
Monounsaturated
Fatty Acids
Branched
monounsaturated
fatty acids
Linear chain
polyunsaturated fatty
acids
Branched chain
polyunsaturated fatty
acids

Fig. 8 The distribution of UFAs reported from marine organisms.

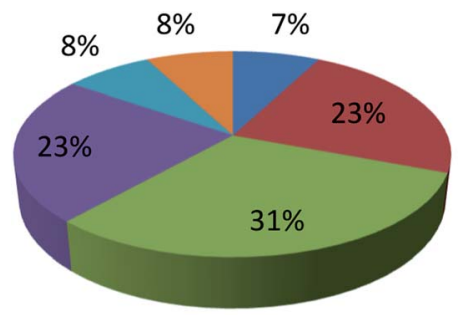

Sea Cucumber
Sponges
Algae
$\square$ limpet
$\square$ Microorganisms
Coral

Fig. 9 Origin of branched monounsaturated fatty acids.

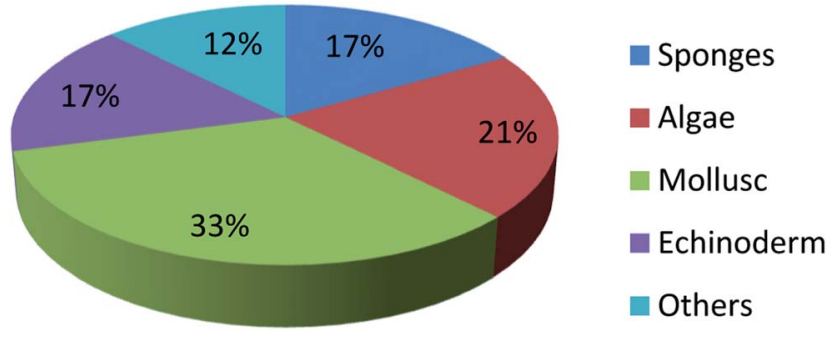

Fig. 10 Origin of linear chain polyunsaturated fatty acids.

biosynthetic processes of most isolated UFAs of marine resources. ${ }^{70,94}$ Thus, more investigation should be carried out for these marine derived UFAs in the coming researches (Fig. 6).

\section{Beneficial application}

It is well-known that polyunsaturated fatty acids n-3 (PUFAn-3) are very important for human health and nutrition. ${ }^{1}$ As an example, highly unsaturated long-chain omega- 3 fatty acids, derived from the liver of white lean fish, flesh of fatty fish, and blubber of marine mammals, exhibit important biological activities. ${ }^{95}$ They also serve as the building block fatty acids in the brain, retina, and other organs with electrical activity. Hence, inclusion of oils containing docosahexaenoic acid (DHA) in the diet of pregnant and lactating women as well as infants is encouraged. ${ }^{95}$

In addition, some polyunsaturated fatty acids from marine microalgae are found to modulate lipid metabolism disorders and gut microbiota. ${ }^{96}$ According to the survey results, high saturated fatty acid and high monounsaturated fatty acid diets have an adverse effect on the gut microbiota and high saturated fatty acids are associated with unhealthy metabolic status, while polyunsaturated fatty acid does not have a negative impact on gut microbiota. ${ }^{97}$ Through previous studies we find that connecting with gut microbiota, PUFAs can be more beneficial for human health. For example, increasing antiobesogenic microbial species in the gut microbiota population by appropriate n-3 PUFAs can be an effective way to control or prevent metabolic diseases. ${ }^{98}$ Furthermore, a link has been established between n-3 PUFAs and gut microbiota especially with respect to inflammation (Fig. 7). A few related researchs show that after omega-3 PUFA supplementation, Faecalibacterium, often associated with an increase in the Bacteroidetes and butyrate-producing bacteria belonging to the Lachnospiraceae family, has decreased. Omega-3 PUFAs perform a positive action on diseases by reverting the microbiota composition and increasing the production of antiinflammatory compounds like short-chain fatty acids. ${ }^{99}$ According to the link between n-3 PUFAs and gut microbiota, which is associated with inflammation, some scholars proposing that an optimal level of LC-PUFAs nurtures the suitable gut microbiota that will prevent dysbiosis. The synergy between optimal LC-PUFAs and gut microbiota helps the immune system overcome the immunosuppressive tumour microenvironment. ${ }^{100}$

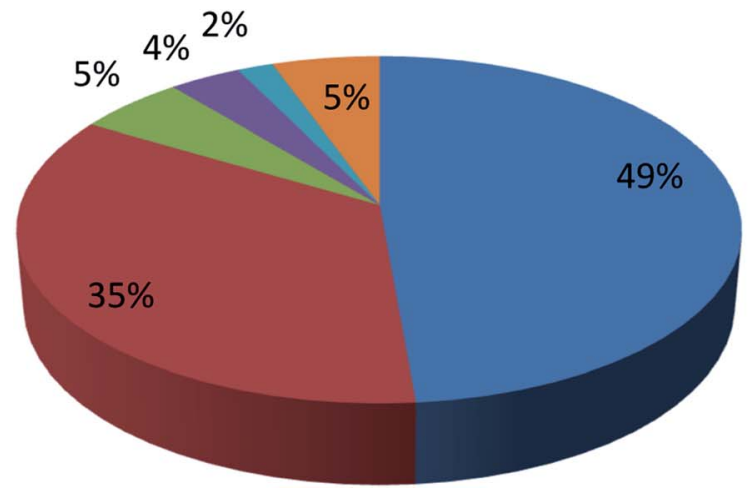

Sponges

Algae

Coelenterate

Marine fungus

Arthropoda

Bacterium

Fig. 11 Origin of branched chain polyunsaturated fatty acids. 
Although many scholars have devoted themselves to the study of polyunsaturated fatty acids, they are limited to the more famous unsaturated fatty acids. There is still lack of investigation of the beneficial application of these polyunsaturated fatty acid derivatives with similar structural characteristics. Thus, more investigation should focus on fatty acid physiological roles and applications in human health and disease and the interaction with gut microbiota. ${ }^{\mathbf{1 0 1}}$

\section{Conclusions}

UFAs are ubiquitous in many marine organisms., ,102,103 $^{\text {, }}$ Although these UFA secondary metabolites have been obtained since the early 20 th century, they only recently draw significant interests because of the diverse range of their biological and nutritional properties. ${ }^{104}$ However, there is still lack of a comprehensive review about the structural characterizations, biological and nutritional properties, proposed biosynthetic processes, and beneficial application of marine derived UFAs. 1978 to 2018, the main structural types of UFAs obtained from marine organisms is branched chain PUFAs, accounting for $74 \%$ of the total (Fig. 8), the main natural source of branched monounsaturated fatty acids isolated from marine organisms is coral, accounting for $31 \%$ (Fig. 9), while linear chain polyunsaturated fatty acids obtained from marine organisms is mollusc, accounting for 33\% (Fig. 10), the preponderant natural marine source of PUPAs is arthropoda, accounting for $49 \%$ (Fig. 11). Although omega-3 fatty acid, ${ }^{6}$ eicosapentaenoic acid (EPA) and docosahexaenoic acid (DHA) from marine organisms, have dramatically increased as excellent sources of nutrients, it is indicated that the biological activities of most of the UPAs are not investigated (Tables 1-3), and the little known about the biosynthetic pathways of these isolated UPAs. In addition, there is no report about new UFAs isolated from marine resources during 2016 to 2018. Thus, the further investigation of marine derived PUPAs should focus on their and beneficial application mediated by gut microbiota.

\section{Conflicts of interest}

The authors declare no conflict of interest.

\section{Acknowledgements}

This research was funded by Science and Technology Planning Project of Guangdong Province, Guangzhou Planned Program in Science and Technology, Program of Department of Ocean and Fisheries of Guangdong Province, Natural Science Foundation of Guangdong, Guangdong Provincial Key Laboratory of Applied Botany, South China Botanical Garden, Chinese Academy of Sciences, Finance Special Project of Zhanjiang City, Natural Science Foundation of Guangdong, grant number 2017A020217002, 201803020003, GDME2018C014, 2016A030313151, AB2018004, 2018A01044 and 2018A0303070018.

\section{Notes and references}

1 E. B. Rimm, L. J. Appel, S. E. Chiuve, L. Djousse, M. B. Engler, P. M. Kris-Etherton, D. Mozaffarian, D. S. Siscovick, A. H. Lichtenstein, C. L. C. Hlth, C. E. Prevention, C. C. D. Young, C. C. S. Nursing and C. C. Cardiology, Circulation, 2018, 138, E35-E47.

2 M. E. Riveros and M. A. Retamal, Front. Physiol., 2018, 9, 693.

3 A. Tsoupras, R. Lordan, K. Shiels, S. K. Saha, C. Nasopoulou and I. Zabetakis, Mar. Drugs, 2019, 17.

4 E. Alexandri, A. Raheel, H. Siddiqui, M. I. Choudhary, C. G. Tsiafoulis and I. P. Gerothanassis, Molecules, 2017, 22, 1633-1671.

5 T. Gluck and P. Alter, Vasc. Pharmacol., 2016, 82, 11-19.

6 D. S. Im, Eur. J. Pharmacol., 2016, 785, 36-43.

7 P. Kuppusamy, I. Soundharrajan, S. Srigopalram, M. M. Yusoff, G. P. Maniam, N. Govindan and K. C. Cho, Indian J. Geo-Mar. Sci., 2017, 46, 663-667.

8 M. Masson, T. Loftsson and G. G. Haraldsson, Pharmazie, 2000, 55, 172-177.

9 N. M. Carballeira, M. Pagan and A. D. Rodriguez, J. Nat. Prod., 1998, 61, 1049-1052.

10 N. M. C. Carballeira, C. Clarisa and A. Sostre, J. Nat. Prod., 1996, 59, 1076-1078.

11 M. Perpelescu, M. Tsuda, M. Suzuki, S. Yoshida and J. Kobayashi, Nat. Med., 2004, 58, 86.

12 I. I. Tatli, F. Kong, X. Feng, G. Carter, K. V. Rao and M. T. Hamann, J. Chem. Res., 2008, 50-51, DOI: 10.3184/ $030823408 \times 287131$.

13 H. T. Dang, H. J. Lee, E. S. Yoo, P. B. Shinde, Y. M. Lee, J. Hong, D. K. Kim and J. H. Jung, J. Nat. Prod., 2008, 71, 232-240.

14 G. S. E. Abou-ElWafa, M. Shaaban, K. A. Shaaban, M. E. E. El-Naggar and H. Laatsch, Z. Naturforsch., B: J. Chem. Sci., 2009, 64, 1199-1207.

15 D. R. D.-C. Beukes and T. Michael, Tetrahedron, 1999, 55, 4051-4056.

16 N. M. Carballeira, H. Cruz, C. A. Hill, J. J. De Voss and M. Garson, J. Nat. Prod., 2001, 64, 1426-1429.

17 C. J. Smith, D. Abbanat, V. S. Bernan, W. M. Maiese, M. Greenstein, J. Jompa, A. Tahir and C. M. Ireland, J. Nat. Prod., 2000, 63, 142-145.

18 K. Watanabe, R. Makino, H. Takahashi, K. Iguchi, H. Ohrui and K. Akasaka, Chem. Pharm. Bull., 2008, 56, 861-863.

19 G. Cimino, A. De Giulio, S. De Rosa, S. De Stefano and G. Sodano, J. Nat. Prod., 1985, 48, 22-27.

20 S. Matsunaga, Y. Okada, N. Fusetani and R. W. M. Van Soest, J. Nat. Prod., 2000, 63, 690-691.

21 R. A. C. Barrow and J. Robert, Aust. J. Chem., 1994, 47, 19011918.

22 P. D. Charoenying, D. Huw, D. McKerrecher and R. J. K. Taylor, Tetrahedron Lett., 1996, 37, 1913-1916.

23 Y. G. Guo, M. Gavagnin, C. Salierno and G. Cimino, J. Nat. Prod., 1998, 61, 333-337.

24 A. G. Lopez and H. William, Lipids, 1987, 22, 190-194. 
25 J. R. D. 1. R. Burgess, I. Roger, R. S. Jacobs and A. Butler, Lipids, 1991, 26(2), 162-165.

26 M. Suzuki, I. Wakana, T. Denboh and M. Tatewaki, Phytochemistry, 1996, 43, 63-65.

27 M. V. B. Mikhailova, L. Debra, M. L. Wise, W. H. Gerwick, J. N. Norris and R. S. Jacobs, Lipids, 1995, 30, 583-589.

28 N. M. Carballeira, E. Anastacio, J. Salva and M. J. Ortega, J. Nat. Prod., 1992, 55, 1783-1786.

29 B. A. Kulkarni, A. Chattopadhyay and V. R. Mamdapur, J. Nat. Prod., 1994, 57, 537-538.

30 H. Saito, J. Chromatogr. A, 2007, 1163, 247-259.

31 A. P. Treschow, L. D. Hodges, P. F. A. Wright, P. M. Wynne, N. Kalafatis and T. A. Macrides, Comp. Biochem. Physiol., Part B: Biochem. Mol. Biol., 2007, 147, 645-656.

32 D. Sato, Y. Ando, R. Tsujimoto and K. Kawasaki, Lipids, 2001, 36, 1372-1375.

33 V. J. Paul and W. Fenical, Tetrahedron Lett., 1980, 21, 33273330.

34 M. P. V. Mansour, K. John, D. G. Holdsworth, A. E. Jackson and S. I. Blackburn, Phytochemistry, 1999, 50, 541-548.

35 N. T. Carballeira, E. Janice, E. Ayanoglu and C. Djerassi, J. Org. Chem., 1986, 52, 2751-2756.

36 N. M. Carballeira and L. Maldonado, Lipids, 1986, 21, 470471.

37 A. Guerriero, M. D'Ambrosio, F. Pietra, O. Ribes and D. Duhet, J. Nat. Prod., 1990, 53, 57-61.

38 N. M. Carballeira and V. Negron, J. Nat. Prod., 1991, 54, 305309.

39 B. A. Kulkarni, A. Chattopadhyay and V. R. Mamdapur, Nat. Prod. Lett., 1993, 3, 251-255.

40 S. Isaacs, Y. Kshman, S. Loya, A. Hizi and Y. Loya, Tetrahedron, 1993, 49, 10435-10438.

41 H.-Y. Li, S. Matsunaga and N. Fusteani, J. Nat. Prod., 1994, 57, 1464-1467.

42 J. Kobayashi, K. Naitoh, K. Ishida, H. Shigemori and M. Ishibashi, J. Nat. Prod., 1994, 57, 1300-1303.

43 J.-R. H. Dai, F. Yali, J. H. Cardellina II, G. N. Gray and M. R. Boyd, J. Nat. Prod., 1996, 59, 860-865.

44 X. Fu, S. A. Abbas, F. J. Schmitz, I. Vidavsky, M. L. Gross, M. Laney, R. C. Schatzman and R. D. Cabuslay, Tetrahedron, 1997, 53, 799-814.

45 A. Guerriero, C. Debitus, D. Laurent, M. D'Ambrosio and F. Pietra, Tetrahedron Lett., 1998, 39, 6395-6398.

46 J. Shin, Y. Seo, K. W. Cho, J. R. Rho and V. J. Paul, Tetrahedron, 1998, 54, 8711-8720.

47 L. Chill, A. Miroz and Y. Kashman, J. Nat. Prod., 2000, 63, 523-526.

48 Y. Nakao, T. Uehara, S. Matunaga, N. Fusetani and R. W. M. van Soest, J. Nat. Prod., 2002, 65, 922-924.

49 S. Nishimura, S. Matsunaga, M. Shibazaki, K. Suzuki, N. Harada, H. Naoki and N. Fusetani, J. Nat. Prod., 2002, 65, 1353-1356.

50 T. N. Makarieva, E. A. Santalova, I. A. Gorshkova, A. S. Dmitrenok, A. G. Guzii, V. I. Gorbach, V. I. Svetashev and V. A. Stonik, Lipids, 2002, 37, 75-80.

51 Q. C. Zhao, T. A. Mansoor, J. K. Hong, C. O. Lee, K. S. Im, D. S. Lee and J. H. Jung, J. Nat. Prod., 2003, 66, 725-728.
52 H. S. Lee, J. R. Rho, C. J. Sim and J. Shin, J. Nat. Prod., 2003, 66, 566-568.

53 C. Okamoto, Y. Nakao, T. Fujita, T. Iwashita, W. M. van Soest, N. Fusetani and S. Matsunaga, J. Nat. Prod., 2007, 70, 1816-1819.

54 A. A. Salim, J. Rae, F. Fontaine, M. M. Conte, Z. Khalil, S. Martin, R. G. Parton and R. J. Capon, Org. Biomol. Chem., 2010, 8, 3188-3194.

55 E. Manzo, M. L. Ciavatta, G. Villani, M. Varcamonti, S. M. Abu Sayem, R. van Soest and M. Gavagnin, J. Nat. Prod., 2011, 74, 1241-1247.

56 G. Nuzzo, M. L. Ciavatta, G. Villani, E. Manzo, A. Zanfardino, M. Varcamonti and M. Gavagnin, Tetrahedron, 2012, 68, 754-760.

57 E. J. Mejia, L. B. Magranet, N. J. De Voogd, K. TenDyke, D. Y. Qiu, Y. Y. Shen, Z. R. Zhou and P. Crews, J. Nat. Prod., 2013, 76, 425-432.

58 J. H. Cardellina II and R. E. Moore, Tetrahedron, 1980, 36, 993-996.

59 M. D. Higgs and L. J. Mulheirn, Tetrahedron, 1981, 37, 42594262.

60 L. Z. Semmak, Abdelfetta, R. Valls, B. Banaigs, G. Jeanty and C. Francisco, Phytochemistry, 1988, 27, 2347-2349.

61 A. G. Lopez and H. William, Tetrahedron Lett., 1988, 29, 1505-1506.

62 M. D. Higgs, Tetrahedron, 1981, 37, 4255-4258.

63 M. G. Bernart and H. William, Tetrahedron Lett., 1988, 29, 2015-2018.

64 F. Asari, T. Kusumi and H. Kakisawa, J. Nat. Prod., 1989, 52, 1167-1169.

65 M. L. J. Solem, D. Zhi and W. H. Gerwick, Lipids, 1989, 24, 256-260.

66 S. Lumin and J. R. Falck, Tetrahedron Lett., 1990, 31, 29712974.

67 M. W. Bernart, G. G. Whatley and W. H. Gerwick, Nat. Prod., 1993, 56(2), 245-259.

68 P. J. G. Proteau and H. William, Lipids, 1993, 28, 783-787.

69 A. Guerriero, M. D'Ambrosio and F. Pietra, Helv. Chim. Acta, 1990, 73, 2183-2189.

70 W. H. Gerwick, P. Aasen and M. Hamberg, Phytochemistry, 1993, 34, 1029-1033.

71 M. W. G. Bernari and H. William, Phytochemistry, 1994, 36, 1233-1240.

72 Z. D. K. Jiang, O. Sharon and W. H. Gerwick, Phytochemistry, 2000, 53, 129-133.

73 M. F. Qiao, N. Y. Ji, F. P. Miao and X. L. Yin, Magn. Reson. Chem., 2011, 49, 366-369.

74 S. C. Mao, D. Q. Liu, X. Q. Yu and X. P. Lai, Biochem. Syst. Ecol., 2011, 39, 253-257.

75 A. D. A. Guerriero, Michele, F. Pietra, O. Ribes and D. Duhet, Helv. Chim. Acta, 1988, 71, 1094-1100.

76 V. Di Marzo, M. Ventriglia, E. Mollo, M. Mosca and G. Cimino, Experientia, 1996, 52, 834-838.

77 N. M. R. Carballeira, D. Elba, A. Sostre, A. D. Rodriguez, J. L. Rodriguez and F. A. Gonzalez, J. Nat. Prod., 1997, 60, 502-504. 
78 T. Yamashita, Y. Nakao, S. Matsunaga, T. Oikawa, Y. Imahara and N. Fusetani, Bioorg. Med. Chem., 2009, 17, 2181-2184.

79 A. Guerriero, M. D'Ambrosio, V. Cuomo, F. Vanzanella and F. Pietra, Helv. Chim. Acta, 1989, 72, 438-446.

80 A. Guerriero, M. D'Ambrosio, V. Cuomo, F. Vanzanella and F. Pietra, Helv. Chim. Acta, 1988, 71, 57-61.

81 K. Trisuwan, V. Rukachaisirikul, S. Phongpaichit, S. Preedanon and J. Sakayaroj, Arch. Pharmacal Res., 2011, 34, 709-714.

82 L. Calcul, C. Waterman, W. S. Ma, M. D. Lebar, C. Harter, T. Mutka, L. Morton, P. Maignan, A. Van Olphen, D. E. Kyle, L. Vrijmoed, K. L. Pang, C. Pearce and B. J. Baker, Mar. Drugs, 2013, 11, 5036-5050.

83 T. K. M. Shing, K. H. Gibson, J. R. Wiley and I. F. Watt, Tetrahedron Lett., 1994, 35, 1067-1070.

84 B. H. Maskrey, G. W. Taylor and A. F. Rowley, J. Exp. Biol., 2006, 209, 558-566.

85 K. Gustafson, M. Roman and W. Fenical, J. Am. Chem. Soc., 1989, 111, 7519-7524.

86 M. A. M. Mondol, J. H. Kim, M. A. Lee, F. S. Tareq, H. S. Lee, Y. J. Lee and H. J. Shin, J. Nat. Prod., 2011, 74, 1606-1612.

87 M. A. M. T. Mondol, F. Shahidullah, Ji H. Kim, M. ah Lee, H.-S. Lee, Y.-J. Lee, J. S. Lee and H. J. Shin, J. Nat. Prod., 2011, 74, 2582-2587.

88 M. A. M. Mondol, F. S. Tareq, J. H. Kim, M. A. Lee, H. S. Lee, J. S. Lee, Y. J. Lee and H. J. Shin, J. Antibiot., 2013, 66, 89-95.

89 X. Xie, D. Meesapyodsuk and X. Qiu, Appl. Microbiol. Biotechnol., 2018, 102, 847-856.

90 K. T. Peng, C. N. Zheng, J. Xue, X. Y. Chen, W. D. Yang, J. S. Liu, W. B. Bai and H. Y. Li, J. Agric. Food Chem., 2014, 62, 8773-8776.
91 Q. H. Zhang, C. H. You, F. Liu, W. D. Zhu, S. Q. Wang, D. Z. Xie, O. Monroig, D. R. Tocher and Y. Y. Li, Lipids, 2016, 51, 1051-1063.

92 M. Vagner and E. Santigosa, Aquaculture, 2011, 315, 131143.

93 R. Vaezi, J. A. Napier and O. Sayanova, Mar. Drugs, 2013, 11, 5116-5129.

94 N. T. Carballeira, E. Janice, E. Ayanoglu and C. Djerassi, J. Org. Chem., 1986, 51, 2751-2756.

95 F. Shahidi, Advances in Seafood Byproducts, 2002 Conference Proceedings, 2003, pp. 247-263.

96 T.-T. T. Li, Ai-Jun, Y.-Y. Liu, Zi-R. Huang, Xu-Z. Wan, Yu-Y. Pan, R.-B. Jia, B. Liu, X.-H. Chen and C. Zhao, Food Chem. Toxicol., 2019, 131.

97 M. Wolters, J. Ahrens, M. Romani-Perez, C. Watkins, Y. Sanz, A. Benitez-Paez, C. Stanton and K. Gunther, Clinical nutrition, Edinburgh, Scotland, 2018, DOI: 10.1016/j.clnu.2018.12.024.

98 J. Bellenger, S. Bellenger, Q. Escoula, C. Bidu and M. Narce, Biochimie, 2019, 159, 66-71.

99 L. Costantini, R. Molinari, B. Farinon and N. Merendino, Int. J. Mol. Sci., 2017, 18, 18.

100 L. L. Ilag, Medicines, Basel, Switzerland, 2018, vol. 5.

101 E. Tvrzicka, L. S. Kremmyda, B. Stankova and A. Zak, Biomed. Pap., 2011, 155, 117-130.

102 E. Kostetsky, N. Chopenko, M. Barkina, P. Velansky and N. Sanina, Mar. Drugs, 2018, 16.

103 S. H. Jonasdottir, Mar. Drugs, 2019, 17.

104 R. B. S. S. Nogueira, A. C. A. Tomaz, D. R. Pessoa, A. L. Xavier, J. C. L. R. Pita, M. V. Sobral, M. L. C. Pontes, H. L. F. Pessoa, M. F. F. M. Diniz, G. E. C. Miranda, M. A. R. Vieira, M. O. M. Marques, M. D. V. Souza and E. V. L. Cunha, Mar. Drugs, 2017, 15. 